\title{
Resource Allocation Orientation of Shipping and Marine Engineering Equipment Manufacturing Industry
}

\author{
Pan Mengling ${ }^{1, a}$, Zhang Yunhua ${ }^{1, b,{ }^{*},}$ Sheng Yongxiang ${ }^{1, c}$ \\ ${ }^{1}$ School of economics and management, jiangsu university of science and technology, zhenjiang, \\ jiangsu, China \\ a630310914@qq.com, ${ }^{\mathrm{b}} 546019357 @ q q . c o m,{ }^{\mathrm{c}} 2638473070 @ q q . c o m$ \\ ${ }^{*}$ Corresponding author
}

Keywords: The ship; Marine engineering equipment; Resource allocation; guide

\begin{abstract}
Ship and ocean engineering equipment industry in jiangsu province during the period of "twelfth five-year" realized leap-forward development, become China's first big province of shipbuilding and the important industrial base, established a research and development, design, shipbuilding, Marine engineering equipment, ship repairing, scrapping, supporting and services and so on all kinds of Marine industries, industry growing international status and market influence. In this paper, the development orientation is put forward from the aspects of industry development, regional layout, intellectual property resource allocation and so on.
\end{abstract}

\section{船舶与海洋工程装备制造产业资源配置导向 \\ 潘梦灵 ${ }^{1, a}$ ，张运华 ${ }^{1, b,{ }^{*}}$ ，盛永祥 ${ }^{1, c}$ \\ 1 江苏科技大学 经济管理学院, 江苏 镇江, 中国

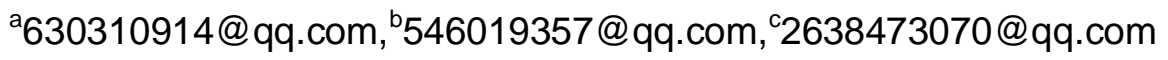 \\ *通讯作者}

关键词：船舶；海洋工程装备；资源配置；导向

中文摘要：江苏省船舶与海洋工程装备产业“十二五”期间实现了跨越式发展，成为我国第一 造船大省和世界重要的产业基地, 建立了研发、设计、造船、海洋工程装备、修船、拆船、 配套及服务等门类齐全的船舶产业体系，产业国际地位和市场影响力不断增强。文章针对船 舶与海洋工程装备制造领域的产业发展、区域布局、知识产权资源配置等方面提出发展导向。

\section{1. 产业发展导向}

江苏省船舶与海洋工程装备产业已经建立了造船和海洋工程装备等门类齐全的船舶产业 体系，正处于船舶工业大省向强省跨越阶段 ${ }^{[1,2]}$ 。在发展目标上要继续保持集装箱船、散货船、 油船三大主流船型尤其是超大型船舶的市场份额, 形成以特种海洋工程船、自升式钻井平台、 半潜式平台、天然气装备为引领的海工产品结构 ${ }^{[3,4]}$ 。如表 1 所示。 
表 1 船舶与海洋工程装备产业发展导向

\begin{tabular}{|c|c|c|}
\hline 产业领域 & 目前主要产品 & 发展重点产品 \\
\hline 船舶制造业 & $\begin{array}{l}\text { 1、集装箱船、超大型散货、超级油轮、散 } \\
\text { 货自卸船、多用途干货船等一般用途船舶。 } \\
\text { 2、多功能全回转工作船、多用途海洋工程 } \\
\text { 船、挖泥船、多用途干货船等特种用途船 } \\
\text { 舶。 } \\
\text { 3、双燃料船、液化气等绿节能船。 }\end{array}$ & $\begin{array}{l}\text { 重点发展超大集装箱船、超大型散货船、双 } \\
\text { 燃料船、汽车滚装船、多功能全回转工作船 } \\
\text { 等高技术、高附加值、绿色节能船舶。 }\end{array}$ \\
\hline 海洋工程装备业 & $\begin{array}{l}\text { 1、圆筒型超深水海洋钻探储油平台、圆筒 } \\
\text { 型 FPSO、半潜式海洋钻井平台、自升式海 } \\
\text { 洋工作平台、八角型钻井平台、半潜式石 } \\
\text { 油钻井平台等平台。 } \\
\text { 2、潜水支持船、大型自航半潜船、海上起 } \\
\text { 重船、大型铺管船、风电安装船等海工船。 }\end{array}$ & $\begin{array}{c}\text { 重点发展圆筒型超深水海洋钻探储油平台、 } \\
\text { 圆筒型 FPSO、自升自航式平台、高端的海 } \\
\text { 洋工程辅助船和风电安装船等。 }\end{array}$ \\
\hline
\end{tabular}

由表 1 可见，重点打造大型散货船、汽车滚装船和多用途船等主力船型的品牌，以“专、 精、特”为方向建造大型液化石油气船和 3 万吨以下高标准不锈钢化学品船等绿色节能船舶。 重点发展半潜式钻井平台、自升式海上多功能服务平台、张力腿平台（TLP）、深水立柱式平 台 (SPAR)、浮式生产储卸装置（FPSO、FLNG）、铺管船等海工装备，逐步形成具有自主知 识产权的品牌产品。

\section{2. 区域布局导向}

目前，江苏已经形成了南通、泰州、扬州、镇江四大船舶与海工装备产业集群，但是江 苏船舶企业内部竞争激烈, 没有整体优势, 尚未形成规模经济效应。因此, 江苏在发展船舶 和海工装备产业的区域布局上要聚集优质资源, 优化产业布局, 做强做优远洋造船基地、打 造海洋工程装备制造基地。

表 2 船舶与海洋工程装备产业区域布局导向

\begin{tabular}{|c|c|c|c|}
\hline 基地 & 区域 & 目前企业数量 & 区域布局导向 \\
\hline 造船基地 & $\begin{array}{c}\text { 南通、泰州、 } \\
\text { 扬州。 }\end{array}$ & 40 & $\begin{array}{c}\text { 做强做优三大远洋造船基地, 重点 } \\
\text { 支持南通、泰州、扬州三个地区产 } \\
\text { 业集聚区。 }\end{array}$ \\
\hline $\begin{array}{c}\text { 海洋工程装备基 } \\
\text { 地 }\end{array}$ & 南通 & 7 & $\begin{array}{c}\text { 打造海洋工程装备制造基地, 重点 } \\
\text { 发展南通为主的苏中地区。 }\end{array}$ \\
\hline
\end{tabular}

由表 2 可见，第一，做强做优三大远洋造船基地。重点支持南通、泰州、扬州三个“产业 集聚、主业突出、特色鲜明”的造船基地, 严格控制新的造船能力建设, 淘汰低端落后产能。 第二, 打造海洋工程装备制造基地。在以南通为主的苏中地区, 建设集研发设计、高端制造 为一体的千亿级海洋工程装备制造基地。

\section{3. 知识产权资源配置导向}

面向船舶制造业和海洋工程装备产业开展核心、关键技术的高价值专利培育工作，依托 中国船舶与海洋工程产业知识产权联盟、知识产权公共服务平台等载体, 建设江苏科技大学 船舶与海洋工程产业高价值专利培育中心, 将关键技术和知识产权服务、产业需求结合, 完 成船舶与海洋工程装备领域亟需各项关键技术的高价值专利产出和专利布局, 形成技术含量 高、法律稳定性高、预期实现效益高的高价值专利群, 服务和带动江苏船舶与海洋工程装备 产业快速发展。 
表 3 船舶与海洋工程装备知识产权资源配置导向

\begin{tabular}{|c|c|c|c|c|}
\hline 产业领域 & 有效专利 & 关键专利布局 & 知识产权运营体系 & 品牌建设 \\
\hline 船舶制造业 & $\begin{array}{l}\text { 、一般用途船舶 } \\
\text { 江苏省有效专利 } \\
29465 \text { 件。 } \\
\text { 2、特殊用途船舶 } \\
\text { 江苏省有效专利 } \\
3472 \text { 件。 } \\
\text { 3、绿色节能船舶 } \\
\text { 江苏省有效专利 } \\
706 \text { 件。 }\end{array}$ & $\begin{array}{l}\text { 高技术、高附加 } \\
\text { 值、绿色、节能的 } \\
\text { 船型研制、高效制 } \\
\text { 造、智能制造形成 } \\
\text { 关键技术的专利 } \\
\text { 布局。 }\end{array}$ & $\begin{array}{l}\text { 以江苏科技大学中-乌 } \\
\text { (江苏) 船舶与海洋工 } \\
\text { 程产业跨国技术转移 } \\
\text { 中心国家级科技服务 } \\
\text { 平台和中国船舶与海 } \\
\text { 洋工程产业知识产权 } \\
\text { 联盟为载体, 构建高技 } \\
\text { 术、高附加值、绿色节 } \\
\text { 能的船舶专利池。 }\end{array}$ & $\begin{array}{l}\text { 打造一批技术先 } \\
\text { 进、建造高效、 } \\
\text { 质量优良、有较 } \\
\text { 高信誉度的国际 } \\
\text { 知名品牌。 }\end{array}$ \\
\hline 海洋工程装备 & $\begin{array}{l}\text { 1、海洋钻井、生 } \\
\text { 产类设备江苏省 } \\
\text { 有效专利 } 1250 \text { 件。 } \\
\text { 2、海洋开发辅助 } \\
\text { 船舶江苏省有效 } \\
\text { 专利 } 21247 \text { 件。 }\end{array}$ & $\begin{array}{l}\text { 在圆筒型超深水 } \\
\text { 海洋钻探储油平 } \\
\text { 台、自升自航式平 } \\
\text { 台、海洋工程船及 } \\
\text { 海上单点系泊系 } \\
\text { 统核心设备形成 } \\
\text { 关键技术的专利 } \\
\text { 布局。 }\end{array}$ & $\begin{array}{l}\text { 以江苏科技大学海洋 } \\
\text { 装备研究院和南通中 } \\
\text { 远船务工程有限公司 } \\
\text { 的海洋工程技术研发 } \\
\text { 中心为载体, 构建具有 } \\
\text { 自主知识产权的大型 } \\
\text { 海工装备产品。 }\end{array}$ & $\begin{array}{l}\text { 加强圆筒型超深 } \\
\text { 水海洋钻探储油 } \\
\text { 平台、圆 筒型 } \\
\text { FPSO、八角型钻 } \\
\text { 井平台, 以及海 } \\
\text { 上风电安装船、 } \\
\text { 钻井辅助船等海 } \\
\text { 工装备制 造领 } \\
\text { 域, 打响国际品 } \\
\text { 牌。 }\end{array}$ \\
\hline
\end{tabular}

\section{1 船舶制造业的知识产权资源配置导向}

(1) 实施关键技术专利布局。江苏省在一般船舶和特殊用途船舶的专利发明授权量和实 用新型授权量与其他省市相比具有明显的优势，处于国内领先水平。随着国际船舶市场持续 深度调整的影响, 江苏骨干船舶企业在承接订单方面竞争更加激烈, 同时世界港口工程、水 利工程、水域环保、桥梁建设等工程的纷纷上马, 高技术、高附加值的大型集装箱船、散货 船的船型研制、高效制造、智能制造以及技术性能先进、功能齐全的专用工程船舶技术将会 获得更多的发展空间。

（2）产业知识产权运营体系建设。中-乌（江苏）船舶与海洋工程产业跨国技术转移中 心，是由江苏科技大学与乌克兰马卡洛夫国立造船大学联合设立的国际技术转移载体。通过 引进乌克兰国立造船大学及乌克兰其他科研单位技术研发团队常驻江苏, 与江苏科技大学及 省内企业联合开展协同创新; 积极为省内企业解决技术难题，提供技术咨询和服务; 重点推 进高价值专利的培育、核心技术的专利布局, 推进产学研合作的专利技术转移, 实施技术标 准中的专利战略, 帮助实施企业知识产权管理的标准化建设, 建设面向行业的知识产权协同 服务平台。

（3）提升品牌形象。企业应培育和弘扬精益求精的工匠精神, 全面推进船舶产品品质升 级, 提升自身产品品牌形象, 拓展已有的大洋“皇冠”系列散货船和金陵 “白暨豚”系列品牌, 形成品牌效应系列船型, 打造一批技术先进、成本经济、建造高效、质量优良、有较高信誉 度的国际知名品牌。

\section{2 海工装备业的知识产权资源配置导向}

（1）实施关键技术专利布局。江苏省的海洋工程装备产业主要授权专利集中水处理、分 离技术、土层钻进、船舶, 分别占国内的 $57.77 \% 、 6.57 \% 、 6.35 \% 、 5.28 \%$; 高校占比达到 $70 \%$ 、 企业占比约 $30 \%$; 自升自航式平台研发、400 英尺自升式大桩靴钻井平台、高端海洋工程辅 助船具有技术优势。

(2) 产业知识产权运营体系建设。江苏科技大学的海洋装备工程研究院拥有中乌技术转 移中心江苏省海洋装备军民融合研发中心、中国船舶与海洋工程产业知识产权联盟秘书处、 
江苏省船舶工业行业协会秘书处等多个功能平台, 拥有稳定海洋工程装备的研发和产业化队 伍。南通中远船务工程有限公司的工程技术研究中心, 是国家级的技术研发中心, 先后设计 建造了圆筒型超深水海洋钻探储油平台、圆筒型 FPSO、半潜式海洋钻井平台、自升式海洋工 作平台、八角型钻井平台, 以及海上风电安装船、穿梭油轮、海洋生活服务平台、钻井辅助 船等一系列海工产品, 多个高端海工产品成功交付, 覆盖了从浅海到深海、从油气平台到海 洋工程船舶的各种类型, 在世界海洋工程装备制造领域打响了品牌, 并已成为中国海洋工程 装备制造领域的领跑者。

(3) 推进海洋钻探平台和海工船建设, 适应低油价的经济型自升式钻井平台开发取得成 果、首个圆筒型 FPSO 关键技术取得阶段性进展、高端的海洋工程辅助船具有世界先进水平, 加强圆筒型超深水海洋钻探储油平台、圆筒型 FPSO、八角型钻井平台, 以及海上风电安装船、 钻井辅助船等海工装备制造领域, 打响国际自主品牌。

\section{致谢}

本文为国家自然资金“创新生态系统中知识主体协同行为与价值创造的耦合机理及提升 策略研究” (71771161) 和江苏省高校哲学社会科学重点研究基地重大项目“船舶产业转型升 级的方法、路径和对策研究”（2015JDXM025）的阶段性研究成果之一。

\section{References}

[1] Xia jifu. Jianghai linkage transformation and upgrading of jiangsu ship and Marine equipment industry and its future development prospects $[\mathrm{J}]$. Chinese and foreign ship science and technology, 2016(1):1-4.

[2] Song yuqing, li yan, lu jiping, et al. Patent analysis of zhenjiang ship and Marine engineering equipment industry -- based on niche theory [J]. Journal of information, 2016, 35(4):105-111.

[3] Lv longde. Outstanding achievements in "dual-tube" shipbuilding in jiangsu [J]. Guangdong shipbuilding, 2016, 35(6):8-9.

[4] Zhou wenkui. Research on the development of jiangsu ocean engineering equipment industry [J]. Contemporary economics, 2015(26):12-14. 